\title{
Non-linguistics Problems in Teaching of Indonesian Language
}

\author{
Rustam Effendi ${ }^{1}$, and Fatchul Mu' in ${ }^{2 *}$ \\ ${ }^{1}$ Lambung Mangkurat University, Department of Language and Arts Education, Jalan Brigjend H. \\ Hasan Basry-Banjarmasin 70123 Indonesia \\ ${ }^{2}$ Lambung Mangkurat University, Department of Language and Arts Education, Jalan Brigjend H. \\ Hasan Basry-Banjarmasin 70123 Indonesia
}

\begin{abstract}
There are two kinds of problems in the teaching of a language, namely: linguistic and nonlinguistic problems. These two problems must be handled in balance so that the teaching of language can reach the objective optimally. It is a fact that the non-linguistic problem is not yet seen as a problem in the teaching of a language. Every strategy of a language teaching is done entirely in order to handle the linguistic problems. The consequence of strategies which neglect non-linguistic problems is a less satisfactory result of the language teaching. There are some non-linguistic problems in the teaching of Bahasa Indonesia, some of them are elaborated in this paper, namely: (i) the interlanguage contact in Indonesia, (ii) the attitude of Indonesian people to Bahasa Indonesia, (iii) feeling that Bahasa Indonesia has been spoken well, (iv) legal sanction to those who look down upon Bahasa Indonesia is unavailable yet. (v) teaching materials, especially teaching materials of other than Bahasa Indonesia pay less attention to good and right language, and (vi) not many people can be followed as example in speaking Bahasa Indonesia.
\end{abstract}

Key Words: linguistic problems, non-linguistic problems, language teaching

\section{Introduction}

There are two problems on language teaching, namely: problems related to linguistics (linguistic problems) and non-linguistics (non-linguistic problems). The linguistic problems are problems which exist or come from inside the language itself. Non-linguistic problems are the problems that derive from the outside of the language, but come from outside the language or language external factors.

In simple way we say that linguistics is defined as the scientific study of language. Linguistics or language science is always related to the rules or principles of a language.. From different viewpoints, as a science, linguistics can be divided into several branches, among others, descriptive linguistics and historical/comparative linguistics (if it is based its methodology), synchronic and diachronic linguistics (if is based on its aspect of time), and phonetics, phonology, morphology, syntax and semantics (if it is based on a language as a system).

\footnotetext{
*Corresponding author: muin_sihyar@yahoo.com
} 
A language itself refers to a systematic sound symbols (see Soeparno, 2013; Chaer, 1994). The more complicated definition of language can be seen in the following. Language is a system of arbitrary vocal symbols, which permit all people in a given culture, or other people who have learned the system of that culture to communicate or to interact (Finocchiaro, 1964).

Related to that, a language is not just spoken or written as the speaker or writer like. The speaker or writer cannot assume that the language that he or she uses can always be understood by other people as the listeners and/or the readers. The expected language is a good and right language. Good because the language is suitable with the situation when it is being used and right because the language is suitable to the grammatical principles of the language (see Alwi, Dardjowidjojo, Lapoliwa, \& Moeliono, 2000).

A language is not only studied based on the internal language itself but also based on the external perspective. From the internal side, it is discussed based on its internal structures of the language; while from the external perspective, the study is based on the linguistic perspectives related to the non-linguistic phenomena influencing the use of language. A study of internal language structures (or, it is based on the sub-systems of a language) will result sub-discipline of linguistics such as phonetics, phonology, morphology, syntax and semantics. It is conducted through theories and procedures belonging to the discipline of linguistics; it is not related to the problems beyond the language (Mariani \& Mu'in, 2006).

Making people speak well and right happens in schools through the teaching of Bahasa Indonesia. Children in schools are taught the standard Bahasa Indonesia, the language which language systems have been standardized. The standardization of language in Indonesia comprises the standardization of the vocabulary by which Kamus Besar Bahasa Indonesia (The Dictionary of Bahasa Indonesia) is the reference of the standard vocabulary, the spelling of Bahasa Indonesia by which Pedoman Umum Ejaan Bahasa Indonesia, Edisi Keempat (the General Guidelines of Bahasa Indonesia Spelling, Fourth Edition) as the spelling reference, and standardized grammar by which Tata Bahasa Baku Bahasa Indonesia, (the Standardized Indonesian Grammar) by Hasan Alwi and friends as the reference for the formation of standard words and sentences.

All the instruments for the language standardization above are used as teaching materials for the teaching of Bahasa Indonesia at schools. The objective of Bahasa Indonesia teaching is the use of good and right (standard) language use. The teaching of Standardized Indonesian Language (Bahasa Indonesia) cannot be reached easily without extraordinary efforts by teachers and students. The good and standardized language with several systems intended becomes linguistic problems in the teaching of Indonesian Language (Bahasa Indonesia). Students must know and master the standardized vocabulary, diction, correct pronunciation, correct word formation, the use of phrases, clauses and correct sentences, and all other things related to the language systems.

The main objective of the learning of Indonesian Language (Bahasa Indonesia) from the elementary to senior high schools is the language skills. Related to this objective, the learning of Indonesian Language (Bahasa Indonesia) is concentrated on the learning of listening, speaking, reading, and writing skills (see Tarigan, 1994). The expected result from the learning of all the language skills is that students have skills in using oral as well as written language well and correclt. It means, although the learning objective and the implementation looks like neglecting the grammatical aspect, the final objective of all the language skills is that students are skillful in using Indonesian Language (Bahasa Indonesia) with correct system of the language. For this objective, the learning material for listening, speaking, reading and writing must be in the forms of linguistically guaranteed sentences and/or texts. 
This paper does not talk about the linguistic problems as what has been stated above. This paper wants to explain non-linguistic problems, problems of language teaching which come from outside the language itself. Non-linguistic problems mean talking about language teaching problems without relating it with the lingulistic principles. This paper has been written based on the result of research in which the writers used the qualitative research approach. Denzin \& Lincoln (1994:2) said, "Qualitative research is multimethod in focus, involving an interpretive, naturalistic approach to its subject matter. This means that qualitative research study in their natural setting, attempting to make sense of interpret phenomena in terms of the meanings people bring to them. Qualitative research involves the studied use and collection of a variety of empirical materials - case study, personal experience, introspective, life story, interview, observational, historical, interactional, and visual text - that describe routine and problematic moment and meaning in individuals'lives.

Data were collected through listening, observation, introspection, and documentation. The researchers conducted the research : (1) through listening and observing the speakers' talks in the various language activities, such as at the office, school, and drinking shops, (2) through documentation based on which we collected data using documents, such as newspapers, papers, advertisements posted on the roadsides, and so on (see Mahsun, 2011), and (3) through introspection by which we utilized the language intuition to obtain data (Chelliah, 2011: 400).

There are some problems in the learning of non-linguistics of learning Bahasa Indonesia. Among the non-linguistic problems which will be explained in this paper are: (i) contact among languages in Indonesia, (ii) the attitude of Indonesian people to Bahasa Indonesia, (iii) feeling that Bahasa Indonesia has been mastered and spoken well, (iv) there isn't legal sanction yet to those who look down upon Bahasa Indonesia is of, (v) teaching material, especially for the teaching subjects other than the Bahasa Indonesia subject have less attention to good and right language, and less sample speakers.

\section{Non-linguistic problems in teaching of Bahasa Indonesia}

This part discusses about: (i) interlanguage contact among languages in Indonesia, (ii) the attitude of Indonesian people to Bahasa Indonesia, (iii) feeling that Bahasa Indonesia has been mastered and spoken well, (iv) there is no legal sanction yet to those who look down upon Bahasa Indonesia, (v) teaching material, especially for the teaching subjects beyond the subject of Bahasa Indonesia with less attention towards good and right language, and less samples of speakers.

\subsection{Interlanguage Contact in Indonesia}

At least there are 3 categories of languages living and developing in Indonesia, namely: (1) Indonesian Language (Bahasa Indonesia) as the national language and formal/official language, (2) local languages (such as Bahasa Banjar or Banjarese language and (Dayak language) as those that are living and developing in local areas or regions, being used for local communication and (3) foreign languages (such as English, Arabic, and Mandarin) as those that have been taught in schools since elementary school until senior high schools, even higher education (see Suherdi, 2012).

As a result of language contact between Indonesian and local language (e.g. Banjarese language), from day to day the latter language increasingly leads to death. Many vocabularies of Banjarese language are no longer known by the younger generation of Banjarese at the present time. Crystal, (2003: 79) points out, "... in which the younger generation is increasingly proficient in the new language. Identifying more with it, and finding their first language less relevant to their needs. "The fear of the local language death is also expressed by some linguists who attended the Forum of Language Diversities (the Asia-Europe Meeting) on 4-5 September 2012. One of them said "Strengthening the 
function of the Indonesia language in its capacity as the national language and official language, this condition indirectly placing local languages on the marginal position. In addition, most of the local language has a relatively small number of speakers and have no written tradition. Therefore, it is not surprising that the problem of extinction of local languages becomes serious problems faced by Indonesia (Mahsun, 2012:2).

In the age of 6 years old, the Indonesian children have known only one language, the language of the local region in which they live with their family. Banjarese children who live in Banjarmasin master Banjarese, Javanese who live in part of Javanese island master Javanese language, Madurese children in Madura island, Sundanese children in West Jawa master Sundanese language, etc. Pusat Pembinaan dan Pengembangan Bahasa ( now Badan Pengembangan dan Pembinaan Bahasa) (the Center of the Developing and Founding of Language) inform that results of researches up to 2012, that there are 546 local languages in Indonesia. According to those researches, there are more local languages which are unidentified and it is estimated that the local languages in Indonesia can reach 600 local languages (see Sariono, 2016:4).

After the age of 6 , when children enter the elementary schools, they are introduced to one language, Indonesia Language (Bahasa Indonesia). They try to master Indonesia Language because it has been used as a medium of instruction and mostly the textbooks as the sources of learning materials are written in Indonesian Language. When the mastery of local languages was obtained by the Indonesian children naturally as the result of language acquisition through their experience in using the language in their social life in their surrounding speech community, the mastery of Indonesia Language is obtained by the Indonesian children through education in schools (see Dardjowidjojo, 2016). That is to say that the local language is acquired, whereas Indonesian Language is learned. Indonesia Language is taught in schools since Education of Early Age (Pendidikan Anak Usia Dini) until Senior High Schools (SLTA). The total years of learning Indonesian Language experienced by Indonesian children are fourteen years (two years in PAUD, six years in the elementary school, three years in junior high school, and three years in senior high school).

English begins to be taught to the Indonesian children since they go to the Junior High School (for three years) until the Senior High School (for three years), so is Arabic, The Indonesian children who go to religious schools begin to learn Arabic since they go to Sanawiyah until Aliyah.

Based on the explanation above, all the Indonesian people who have education up to senior high schools are multilinguals. They do not only know their local language (mother tongue) but also know Indonesian Language and a foreign language (English, Arabic and/or other foreign language).

Indonesian Language (Bahasa Indonesia) has two functions, namely : the national language and the state language. The function of Indonesian Language as the National Language was obtained since Bahasa Indonesia was mentioned in the Sumpah Pemuda (Youth Pledge). Sumpah Pemuda was declared by the Indonesian Youth, who built Indonesian Nation in October 28 and the third pledge is about Bahasa Indonesia. Bahasa Indonesia is stated by the pledge as a language which was prepared to be the national language when Indonesia gets its independence (see Alwi, 2011; Alwi \& Sugono, 2011). The content of the third pledge becomes the beginning of the proclamation of Bahasa Indonesia as the language of unity for the Indonesian nation. Sumpah Pemuda (Youth Pledge) written in Ch. A. van Ophuijsen spelling is as follows:

Kami poetra dan poetri Indonesia mengakoe bertoempah darah jang satoe, tanah air Indonesia

Kami poetra dan poetri Indonesia mengakoe berbangsa jang satoe, bangsa 


\section{Indonesia}

Kami poetra dan poetri Indonesia menjoenjoeng bahasa persatoean, Bahasa

Indonesia

The second status of Bahasa Indonesia is as the official language of the state of Republic of Indonesia. The status as the official language of the state was obtained by Bahasa Indonesia since it was written or recorded by the language builder of the Indonesian nation in the 1945 Constitution, Chapter XV, article 36, and by the statement of this article Bahasa Indonesia was stated and inaugurated as the state language.

Three languages that are in Indonesia (the local language, Bahasa Indonesia, the foreign language) are expected to keep their own status and function, do not influence each other and do not compete one another among languages. Seminar Politik Bahasa Nasional/ Indonesia (Seminar of National Language Politics) conducted in Jakarta from 25 to 28 of February, 1975 had formulated the status and function of Bahasa Indonesia, local language and foreign language in Indonesia so that languages in Indonesia do not show contact and can live together (see Hasil Perumusan Seminar Politik Bahasa Nasional, 1975). The formulation of the status and function of the languages are:

As the National Language, Bahasa Indonesia has its function as (1) the symbol of national pride, (2) the symbol of national identity, (3) as unifying force several different communities with different social cultural backgrounds and languages, and (4) connecting tool among cultures among regions.

As the state language, Bahasa Indonesia has the functions of (1) an official state language, (2) an official language for communication in education institutes, (3) an official language in national communication nationally for the planning and executing development and government administration, and (4) as an official language in cultural development and use of science and modern technology.

Local languages have the status of local languages. A local language is one of the elements of national culture protected by the government (Explanation of article 36, Chapter XV, 1945 Constitution. In the status of the local languages in Indonesia function as (1) symbols of local prides, (2) symbols of local identity, and (3) communication tools in the family and the local community. Related to the function of Bahasa Indonesia, the local languages also function as (1) supports to the national language (2) language of communication in the elementary schools in certain regions in the beginning, to accelerate the teaching of Bahasa Indonesia and other subjects, and (3) tool for the development and support local culture.

All languages other than Bahasa Indonesia and local languages (like English, Arabic and the others) are called foreign language. Foreign languages functions as (1) media communication among nations, (2) development tool to make possible for Bahasa Indonesia develops to a modern language, and (3) as tool to use in science and modern technology for national development.

With the status and function of languages above, it is expected that three languages living in Indonesia consistently make use of the formulation. With the status and function of the language, it is expected that the three languages living in Indonesia consistently use the formulation as a guide. Bahasa Indonesia does not take the function of the local language and/or the foreign language, and vice versa. All languages live with their nature directed by the national language politics.

National language political wills that all languages living in Indonesia can live side by side peacefully, cannot be fulfilled entirely. By the Indonesian community, being realized or not, Bahasa Indonesia is considered to be a more prestige than the local languages, This makes local languages, day by day, being chaos, buried and abandoned by their speakers because of the intervention of Bahasa Indonesia. Then, English, by some of the Indonesian 
community, English is considered to be more prestige compared to Bahasa Indonesia. English shows more and more power and goes to the social life of the community where Bahasa Indonesia should have its status and function. As the result of this contact, local languages become mixed language ( seen from the mixed vocabulary) and there are worries that someday local languages will extinct because the vocabulary has been replaced by the vocabulary of the more prestige language, Bahasa Indonesia. So is bahasa Indonesia, although not as serious as local languages ( because Bahasa Indonesia is always being guarded by Badan Bahasa (Language Authority), the consequence/result of the intervention of English to the status and function of Bahasa Indonesia, some people's loyalty of the Indonesian people will be crushed more and more. The aspiration of Sumpah Pemuda that all Indonesian people 'menjoenjoeng' the language for Indonesia will be more and more difficult to reach.

Languages supported by less people in the community, by experts, are called minority language and languages with more loyal users are called majority language. Majority languages tend to influence even kill the minority languages. The majority and minority language and cultural issues have become global issues. Gibbons and Ramirez stated, "A major challenge for linguistik minorities, whether indigenous, refugee or migrant, is the maintenance of their language and culture. In almost all societies around the world, the nationalist myths that societies are (or can be) homogenous culturally, linguistically and ethnically, have led to the overt or covert suppression and linguistic difference, and sometimes the 'cleansing' of ethnic difference -including genocide- (see Gibbons \& Ramirez, 2004)."

Among the proofs that there is contact between Bahasa Indonesia and English is the great number of articles written by Indonesian scientists using English, even if the writings are put in journals in Indonesia. It also the case in several journals with articles in several languages (like Bahasa Indonesia, English, and Arabic), at least the writer of the article must write the abstract of the article in English. Actually the Indonesian Law No. 24, 2009 Chapter III, article 35 has prohibited the use of foreign languages in writing and publishing articles.

Language contact seen from outside education field has very big impact in the teaching and learning Bahasa Indonesia. Some teachers, moreover those who do not teach Bahasa Indonesia, do not care to give help in reaching the objective of teaching and learning Bahasa Indonesia. At schools, actually teachers and students must use Bahasa Indonesia; but some of them prefer to use the local language. In the classroom, consciously or not, often use the local language to explain. Some schools also open special class using English as the medium of communication to explain the subject. This situation makes the objective of the teaching and learning Bahasa Indonesia is difficult to reach.

\subsection{Speakers' Attitude to Bahasa Indonesia}

The non-linguistic problem of the teaching of Bahasa Indonesia other than contact among languages is the attitude of the speakers of the language, like considering certain language lower than the other prestige languages. It is fact that cannot be denied some Indonesian people consider Bahasa Indonesia lower than foreign languages especially English. They are less loyal to their own language. This unloyalty or negative attitude can be seen in the commercials which are put along the street. Almost $90 \%$ of the commercials use English or local language, although the words can be changed to Bahasa Indonesia.

The unloyal attitude to Bahasa Indonesia is not only seen in the big business with big capitals, but also in small businesses such as beauty salons in small places (kampung). Among the words written are ladies and gent which can actually be written in Bahasa Indonesia as pria dan wanita. The unloyal attitude is seen more in businesses with big 
capital like cigarettes, big trade business, housing complexes etc. Actually the Indonesian Law Number 24, 2009, Chapter III, article 36, point 3, written:

"Bahasa Indonesia wajib digunakan untuk nama bangunan atau gedung, jalan, apartemen, atau permukiman, perkantoran, kompleks perdagangan, merek dagang, lembaga usaha, lembaga pendidikan, organisasi yang didirikan atau dimiliki oleh warga negara Indonesia atau badan hukum Indonesia." (Bahasa Indonesia must be used to name building, streets, apartments, housings, trade complexes, business marks, business institutes, and education institutes, organizations built or owned by Indonesian citizen or legal organization)

The negative attitude of speakers to Bahasa Indonesia also enters the education field. Some teachers and also students feel attracted more to those who can speak well in a foreign language especially in English. Naming rooms at schools is also done in English, for examples: Headmaster for the headmaster's room, Teachers' Rooms, Laboratory, Library, etc, written in English. Because of that situation, feeling love for Bahasa Indonesia is becoming less and less, and reaching the objective of learning Bahasa Indonesia becomes more difficult.

\subsection{Feeling Satisfied to be Able to Use Bahasa Indonesia}

Some of the other Indonesian people consider that Bahasa Indonesia does not need to be seriously learned. Bahasa Indonesia is an easy language and it will be mastered by itself by every Indonesian. This consideration may be true if what is meant by Bahasa Indonesia is ungrammatical, and "as it is like". It is true that almost all Indonesian people are able to understand what is spoken in Bahasa Indonesia and are able to communicate in Bahasa Indonesia (speak). But, again, their ability to speak Bahasa Indonesia is very low, moreover if they must use it in writing.

As the result of considering or feeling that they are able to speak Bahasa Indonesia, the Bahasa Indonesia school subject at school is considered to be very easy and often be neglected. Often time the subject of Bahasa Indonesia is placed at the last periods because it is considered to be an entertainment and relaxation after dealing with other subjects considered to be the main subjects before. Students are competing to chase other subjects considered to be more important like: mathematics, physics, or English although at the end some of them fail to reach what have been left behind.

The consideration that Bahasa Indonesia learning is easy because for some languages originated from Melayu languages, like Banjarese, there are similarities from several sides of the languages. In fact the similarities in most of Melayu languages often cause carelessness in students using Bahasa Indonesia. In Banjar language (Banjarese) there are many Indonesian words that are exactly the same as Banjarese language. However, the similarities are only in words. When the words are formed by putting affixes, then we can find the differences (see Kawi, 2011).

There are words like gula, cari, beri, hadang, and lampu in Bahasa Indonesia and in Banjarese. The similarities are only in the level of words, and after they are being affixed, the meanings are quite different. All the same words above, ln Banjarese can be added by suffix $-i$, so they become gulai, carii, berii, hadangi, dan lampui. So the similarities of words often " cheat" the students who are learning Bahasa Indonesia. They think that the words with the suffix -i above are Bahasa Indonesia. A teacher, from Banjarese etnics, for example, may sometimes make sentences:

Teacher: "Nak, tolong carii Ibu yang mengajar di kelas lima."

Student: "Ya, Bu! Sudah saya carii, Ibunya tidak ada."

Teacher: "Gambar yang kamu buat warna kuningnya kurang tebal. Coba kuningi bagian yang di ujung itu."

Student: Baik Bu. Sudah saya kuningi." 
From the language data above us can see the interference of Banjarese to Bahasa Indonesia, in the words carii and kuningi. The teachers as well as the students are not aware that they have made Banjarese interference to Bahasa Indonesia that they are using. Interference refers to "the use of features belonging to one language while speaking or writing another" (Mackey in Fishman, ed. 1972 :569).

It cannot be denied that the responsibility of using Bahasa Indonesia for the Indonesian people in certain places, for examples in the work place of government or private places of works are not entirely be fulfilled. This is not apart from the attitude of some Indonesian people who tend to look down upon Bahasa Indonesia; they don't have attitude yet to fulfil governments' demand. The heroic event of October heroik and no reason whatsoever to neglect the Sumpah Pemuda. Of course every person who loves and respect the heroes will go along and guard the oaths they stated until it comes true. Not too much if it is said that people who do not guard Bahasa Indonesia are those who cannot respect their heroes.

The responsibility of using bahasa Indonesia in the work place of government and private sectors written in 1945 Constitution of the Republic of Indonesia Number 24 , 2009, Chapter III, Article 33 point 1, "Bahasa Indonesia is compulsory used in official communication in the government and private work places."

\subsection{The Need for Legal Sanction to the Law Breaker of Language Function Stipulation}

Historical background and regulation which tie people to be loyal to Bahasa Indonesia has been very suitable. Sumpah Pemuda of October 28, 1928 was a historical heroic event and no reason whatsoever to neglect to their oath, Of course, everybody who loves and respects their heroes will keep guarding the oath they utter until all the oaths come into reality. It is not too much to say that those who do not guard Bahasa Indonesia are those who do not respect their heroes.

The heroic event of October 28. 1928 was heroically welcomed by the Indonesian fighters. Bahasa Indonesia which was fought and became an oath in the event of Sumpah Pemuda was welcomed by the independence fighters by putting Bahasa Indonesia into the 1945 Indonesian Constitution, Chapter XV, article 36. At last, the Government of Indonesia The government of the Republic Indonesia publish again the Legislation of the Republic of Indonesia No 24, 2009, which contain the rule of the use of bahasa Indonesia, the development, , restoration, and protection of bahasa Indonesia, and the improvement of the function of bahasa Indonesia to be an iinternational language.

All the legal products above have been suitable to be the basic to give sanction to those who underestimate Bahasa Indonesia. Facts show that there are still quite many Indonesian people who do not have loyalty to use Bahasa Indonesia. To those who haven't mastered bahasa Indonesia and use it ambivalently, it is the government's duty to make them speak Bahasa Indonesia well, as the message in the Legislation Number 24, 2009, Chapter III, Section 33 Article 2, which says, "Pegawai di lingkungan kerja lembaga pemerintah dan swasta yang yang belum mampu berbahasa Indonesia wajib mengikuti atau diikutsertakan dalam pembelajaran untuk meraih kemampuan berbahasa Indonesia."। "The government and private employees in governments and private institutions who are not able to speak Bahasa Indonesia must follow or be included in the Bahasa Indonesia learning to get the ability to speak Bahasa Indonesia." For those who are already speaking Bahasa Indonesia well, but not being loyal to Bahasa Indonesia, as is seen on the information board for the commercials of an industrial product are entitled to the legal sanction".

The punishment is based on the 1945 Constitution and Legislation Number 24, 2009 as the operational guidelines. In Laws Number 24, 2009 in: 
a. Article 32 (1),"Bahasa Indonesia is compulsory to be used in national forum and international in Indonesia."

b. Article 32 (2),"Bahasa Indonesia is compulsory to be used in formal communication in government and private work place."

c. Article 35 (1), "Bahasa Indonesia is compulsory to be used in writing scientific articles and publication in Indonesia."

d. Article 36 (3)," Bahasa Indonesia is compulsory to be used to name buildings, street, apartment or housing, offices, trading complex, trade mark, business institutions, educational institutions, organizations owned by the Indonesian citizen or law institutions in Indonesia.

The unavailability of legal sanction for those who underestimate Bahasa Indonesia also has impact to the teaching -and learning of Bahasa Indonesia. All the students see examples of wrong sentences and maybe think of them as correct sentences, students who have been loyal to Bahasa Indonesia see how those who do not obey the language rules are able to express Bahasa Indonesia as they want.

\section{Conclusion}

The non-linguistic problems have influenced the results of teaching and learning Bahasa Indonesia. Non-linguistic problems influence the learning result of Bahasa Indonesia. Consequently, these problems need to be thought and solved by Bahasa Indonesia experts working together with the government of the Republic of Indonesia.

Until now, a lot of efforts have been made by the government through the Language Institution which is related to the non-linguistic problems solution. The latest was the issue of The Republic Indonesia Law Number 24, 2009. One of the content is about the instruction of how to use Bahasa Indonesia in the country: Indonesia as well as the use of Bahasa Indonesia when an Indonesian is outside the country.

Insya Allah, in the future bahasa Indonesia hand in hand with Bahasa Melayu in Malaysia and Brunei Darusslam will become a big language and an international language or formal language in the United Nations (see Collins, 2011).

\section{References}

Alwi, Hasan. 2011. Bahasa Indonesia Pemakai dan Pemakaiannya. Jakarta: Badan Pengembangan dan Pembinaan Bahasa.

Alwi, Hasan \& Dendy Sugono. 2011. Politik Bahasa. Jakarta: Badan Pengembangan dan Pembinaan Bahasa.

Alwi, Hasan. dkk. 2000. Tata Bahasa Baku Bahasa Indonesia. Jakarta: Balai Pustaka.

Chaer, Abdul. 1994. Linguistik Umum. Jakarta: Rineka Cipta.

Collins, James T. 2011. Bahasa Melayu Bahasa Dunia. Jakarta: Yayasan Pustaka Obor Indonesia.

Dardjowidjojo, Soenjono. 2016. Psikolinguistik. Pengantar Pemahaman Bahasa Manusia. Jakarta: Yayasan Pustaka Obor Indonesia.

Denzin. 2005, N.K. \& Lincoln, Y.S. 1994. Handbok of Qualitative Research, Thousand Oaks, CA: Sage

Chelliah, L., Shobhana \& J. De Reuse, Willem. 2011. Handbook of Descriptive Linguistic Fieldwork. New York: Springer.

Crystal, David. 2003. Language Death. Cambridge: Cambridge University Press.

Ellis, Rod. 1995. The Study of Second Language Acquisition. Oxford: Oxford University Press. 
Finocchiaro, Mary. 1989. English as a Second/Foreign Language From Theory to Practice. Fourth Edition. Englewood Cliffs, new Jersey: Prentice Hall Regents

Fishman, J.A. 1972. Language in Sociocultural Change. California : Stanford Universut Press.

Fromkin, Victoria and Robert Rodman, 1978. Introduction to Language. New York : Holt, Rinehart and Winston.

Gibbons, J. \& Ramirez, E. 2004. Maintaining a Minority Language: A Case Study of Hispanic Teenagers. Clevedon, GBR: Multilingual Matters Limited.

Hasil Perumusan Seminar Politik Bahasa Nasional, Jakarta: 25-28 Februari 1975. Jakarta: Pusat Pembinaan dan Pengembangan Bahasa.

Kawi, Djantera. 2011. Telaah Bahasa Banjar. Yogyakarta: Scripta Cedekia.

Mu'in, Fatchul \& Sirajuddin Kamal, 2006. Sociolinguistics: An Introduction. Banjarmasin : Jurusan Bahasa dan Seni FKIP Universitas Lambung Mangkurat.

Mahsun. 2011. Metode Penelitian Bahasa: Tahapan Strategi, Metode, dan Tekniknya. Jakarta: Rajawali Pers.

Mahsun. 2012. The management of Language Diversity in Indonesia: Issues and Policies. Asia Europe Meeting (ASEM). Jakarta, 4-5 September 2012.

Mariani, Nanik \& Mu'in, Fatchul. 2007. Introduction to Linguistics. Banjarmasin : Jurusan PBS FKIP Universitas Lambung Mangkurat.

Sariono, Agus. 2016. Pengantar Dialektologi Panduan Penelitian dengan Metode Dialektometri. Yogyakarta: CAPS (Center for Akademic Publishing Service).

Suherdi, Didi. 2012. Rekonstruksi Pendidikan Bahasa Sebuah Keniscayaan bagi Keuggulan Bangsa. Bandung: CELTICS Press.

Suparno. 2013. Dasar-Dasar Linguistik Umum. Jakarta: Tiara Wacana.

Tarigan, Henry Guntur. 1994. Menyimak Sebagai Suatu Ketrrampilan Berbahasa. Bandung: Angkasa.

Undang-Undang Republik Indonesia Nomor 24 Tahun 2009 Tentang Bendera, Bahasa, dan Lambang Negara, serta Lagu Kebangsaan. Jakarta: Lembaran Negara Republik Indonesia. 